\title{
G. A. Pugaçenkova ve Minyatür Yorumları Üzerine
}

Mublise Rustamova

Galina Anatolyevna Pugaçenkova, 7 Şubat I9Is tarihinde Kazakistan Cumhuriyeti'nin Vernıy ilinde dünyaya geldi. Liseyi bitirdikten sonra 1930 yılında Taşkent Teknik Üniversitesi Mimarlık bölümünü kazandı. 1937 yılında lisansını bitirdikten sonra aynı üniversitenin Orta Asya Mimarisi Tarihi bölümünde yüksek lisansa başladı. 194I yılında doktorasını savundu. I942-1960 yılları arasında Mirza Uluğbek Araştırma Enstitüsü’ nün Tarih ve Arkeoloji bölümünde doçent ünvanıyla bölüm başkanı olarak çalıştı. 1958-ı960 yılları arasında Hamza adındaki sanat enstitüsünde kıdemli araştırmacı olarak çalıştı. 1960 yılından itibaren aynı enstitünün Sanat Tarihi ve Mimarisi bölümünde başkanlık yaptı.

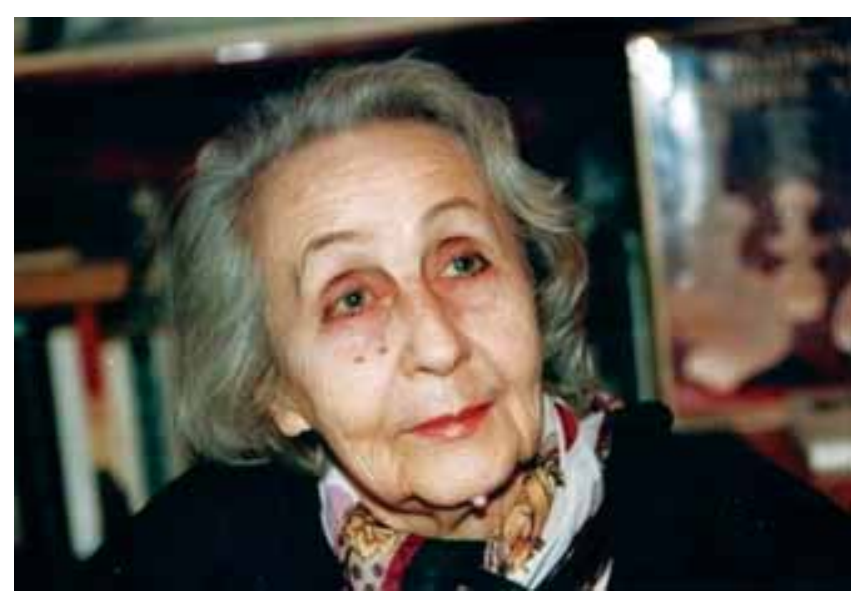


I940'l ylllardan itibaren Özbekistan, Türkmenistan ve Afganistan bölgelerinde yapılan arkeolojik kazılara aktif bir şekilde katıldı. 1946-196ı yılları arasında Güney Türkmenistan'daki yapıların arkeolojik kazılarını yapan VII. Grup'un başkanlığını yaptı (YTKE). Partlar krallığını, antik Baktriya ve Dalverzintepe yerleşik şehrini ve Kampirtepe'yi arkadaşlarıyla birlikte bulan Pugaçenkova, birçok ilmi eserler neşretti.

1959 yılında "Güney Türkmenistan'ın antik çağdan feodal döneme kadar mimari gelişimi” adındaki doçentlik tezini kıdemli bir sanatçı düzeyinde savundu. 1959-1984 yılları arasında Özbek Sanat Tarihi ilmi araştırma grubunun baş danışmanlığını yaptı. 1962 yılında profesör oldu. 1968 yılında Özbekistan Sovyet Sosyalist Cumhuriyeti Bilimler Akademisi'nin muhabiri oldu. 1984 yllinda ise aynı Akademi'ye üye seçildi. 1983 yılında ise "Sovyet Özbekistan' 1 " "Sovetskiy Uzbekistan" adındaki derginin yayın kurulunda yer aldı.

Pugaçenkova ile uzun yıllar birlikte çalışmış olan öğrencileri çeşitli konferanslarda bu efsane bilim kadını hakkında konuşmalar yapmışlardır. İşinde olduğu gibi özel hayatında da düzenli, disiplinli, ciddi ama hep gülümseyen yüzü ile herkesi etkisi altına alabilmiştir. Orta Asya Sanat Tarihinin kurucusu Pugaçenkova'nın asıl mesleği mimarlıktı. $O$, hayatını, önüne çıkan tüm fırsatları en iyi şekilde değerlendirerek kendi istediği bir şekilde kurdu. Onun yaşam tarzı hakkında efsane söylentiler hiç bitmedi; zarifliği, güzel giyinmesi, bakımlılığı, çalışkanlılı̆̆ı, hırsı, zekâsı ve bunlara rağmen sakin duruşu vardı. Pugaçenkova olmadan Orta Asya Sanat Tarihi düşünülemez bile, onun hemen hemen tüm arkeolojik kazılarına, etütlerine katılan yakın arkadaşlarından olan Moskova’daki Doğu Müzesi Müdür yardımcısı Tigran Mkrtırçev onun hakkında şöyle der: “ Ben onun öğrencilerinden biriydim, aslında onun sayısız öğrencisi vardı. Orta Asya sanat tarihinde bilmediği konu yoktu. Bilimsel çalışmalarda bizzat ya da dolaylı olarak elbette onun adı geçerdi. Pugaçenkova’nın geniş ve sistemli düşünme yeteneği, hep hayranlık uyandırmıştır. O, M.Ö. III. yüzyıldan başlayıp XVI. yüzyıl yani Timurlular dönemine kadar olan tarihle ilgilenirdi. Onunla her konuda konuşabilirdik. Bazı tarihçiler, arkeologlar ve sanatçılar onun kitaplarındaki bilgileri yanlış sayıp eleştirirlerdi, ancak öyle değildi. Onlar sadece kendi alanlarını bildikleri için tarih içindeki sürecin akışını, sebep-sonuç ilişkisinin doğurduğu neticeleri göz ardı ederlerdi. Bu yüzden Pugaçenkova haklı çıkardı, çünkü onun engin bilgisi, sistemli düşünmesi, kültür genişliği, sürecin akışını

I Mıktırçev Tigran Konstantinoviç Moskova’da Orta Asya Araştırmaları Devlet Müzesi Müdür Yardımcısı aynı zamanda tarihçi ve arkeolog. İran, Afganistan ve Hindistan Buda anıtları alanında uzmandır. Onlarca kitabın müellifidir, kitapları Rusça ve başka dillere çevrilmiştir. 
tespit ederek sezgileriyle araştırma metodu ve ilmi disiplini son derece önemli yeteneklerinden biriydi. Onun ayrı ayrı bilgileri irdeleyip bir zincir halinde tasnif edebilme yeteneği vardı. Muazzam bilimsel sezgi sahibiydi. Bununla birlikte o İngilizce ve Fransizca dillerini bilir ve zorlanmadan bu dillerde kitaplar okurdu. Orta Asya sanat tarihi bilim dalında okumadığı, göz ardı ettiği bir kitap ve çalışma olduğunu zannetmem. Onun kitapları ansiklopedi gibidir, içinde her şeyi bulabilirsiniz. Bu yüzden Pugaçenkova Orta Asya sanat tarihinde önemli bir şahsiyettir.

Pugaçenkova - Sanat Tarihinin ve arkeolojinin önemini gözler önüne seren ve bilim dünyasında farklılık getiren ve bu iki dalın parlak dönemini yaşatan biridir. Pugaçenkova harika bir editördü, hızlı okur ve önemli yapısal eleştirilerde bulunurdu. Çok sayıdaki uzman ile aynı anda çalışabilirdi. O, kaynakları hemen vermezdi ama fikir ve öneride bulunurdu. Öğrencilerine üstesinden gelebilecekleri konuları çalıştırırdı ve sezgilerinde de yanılmazdı.

Pugaçenkova zamanının en lüks kütüphanesine sahipti. Böyle bir kütüphane hatta Moskova ve Petersburg'da bile yoktu. Bazı öğrencilerine bu ev kütüphanesinde çalışmaları için izin verirdi. Evin içinin her tarafı tavana kadar kitaplarla dolu idi, gerekli olan kitabı hemen yerinden bulur verirdi. Onun evi akademik ve aristokratik yönüyle bir kültür vahası gibiydi. Pugaçenkova gündemi iyi takip eder, yeni çıkan her kitabı, dergiyi gözden geçirirdi, ancak kendi yazdığı kitaplara bakmazdı, onları ezbere bilirdi çünkü. Ancak her şeyden önce kendi işini yapard.

Demir gibi bir karaktere sahipti, kimseden korkmazdı. Bir dönem enstitü müdürü bayanların işe pantolon giyip gelmelerini yasakladı, kararın çıkmasının ertesi günü Pugaçenkova işe pantolonla geldi. Müdür dahil kimse bir şey diyemedi, böylece bu yasak kendiliğinden sessizce ortadan kalkmıştı.

Pugaçenkova az ve öz konuşurdu, bana bir defasında "Tigran şakalarınızı tekrar ediyorsunuz." demişti, bu bana yetmişti. Kazılardaki "özgür ortam” ona tesir etmezdi. O, her zaman mesafeli idi.

I948 yılındaki kazılarda bulunan muhteşem altın ritonlar, Dalverzingtepe'de buldukları $34 \mathrm{~kg}$ altın defne Pugaçenkova ve yanında çalışanların şanslı dönemleriydi, onlara SSCB ve üniversiteler büyük ölçüde yardım ediyorlardı. Pugaçenkova bütün bu işlerde bir lokomotifti.

SSCB'nin dağılmasıyla Pugaçenkova Özbekistan'da yaşamaya devam etti. Ancak iyice yaşlanınca evini ve akademik kütüphanesini ismini saklı tutan birine sattı ve oğlunun evine taşındı. (Pugaçenkova'nın iki oğlu ve bir kızı vardır.) Galina Anatolyevna Pugaçenkova I8 Şubat 2007 yilında Taşkent'te 92 yaşında vefat etti. 
Taşkent'e yakın bir yerdeki Dombrabad adındaki Hıristiyan mezarlığına, ünlü arkeolog olan eşi Masson'un yanına defnedildi.

Özbekistan Sanatı adındaki kitabı günümüzde nadir bir ansiklopedik eser olması bakımından çok önemli bir yere sahiptir. Bu kitapla Pugaçenkova devlet tarafından onur belgesi ile ödüllendirilmiştir. Bu ciddi çalışma günümüzde yeniden ele alınıp yazılsa iyi olurdu, bu görevi Galina Anatolyevna’nın talebelerinin üstleneceklerini umuyoruz."

\section{Ödülleri}

I946 - I940-1945 yılları arasında olan İkinci Dünya Savaşı'nda cesurca hizmet ettiği için ödüllendirildi. (Bu ödül, işçi, teknisyen ve sanayi ve ulaştırmada çalışanlar, çiftçiler ve tarım uzmanları, bilim, teknoloji, sanat ve edebiyatçlar, Sovyet yetkilileri, parti, sendika ve diğer toplum kuruluşlarında çalışan elemanlar için verilmiştir.) 1964- Özbek Sovyet Sosyalist Cumhuriyeti Bilimler Akademisi'nin onurlu bilim adamı ödülü. I966- Rempel ile birlikte çalıştığ 1 "Antik çağdan XIX. yüzyıla kadar Özbekistan'da Sanat Tarihi” adlı eseri için "Hamza" adındaki Özbekistan Sovyet Sosyalist Cumhuriyeti devlet ödülü. 1970- V. İ. Lenin’in doğumunun ıoo. yıldönümünü anma programında gösterdiği hizmetten ötürü aldığı ödül. Lenin Nişanı, SSCB’nin ülke gelişiminde katkıda bulunan; sanatta, bilimde, sporda ve askeri alanlarda başarılı olan kişilere, organizasyonlara, şehirlere verdiği nişandır. 1975- Kızıl Bayrak İşçi Nişanı. Kamu hizmetlerinde gösterdiği başarılar için Sovyetler Birliği tarafından verilmiştir. 1984- Kıdemli emektar nişanı. (veteran of work) 1992- Biruni Devlet Ödülü. 1993- Özbekistan Sanat Akademisi'ne akademisyen olarak seçildi. 1993- Uluslararası Doğu Mimarlık Akademisinin Fahri Doktoru oldu. 1995- Fransa "Akademik Palm"1 ile ödüllendirildi. 2000- Özbekistan Sanat Akademisi tarafından altın madalya ile ödüllendirildi.

Bununla beraber, Galina Anatolyevna Pugaçenkova Orta ve Uzak Doğuda Alman Arkeoloji Enstitüsü ve İtalyan Enstitüsü’nün üyesi, Strasbourg Üniversitesi’nin Fahri Doktoru, Uluslar Arası Doğu Mimarisi Akademisinin fahri üyesi ve birçok tanınmış bilimsel kuruluşlarda üyeliği olan önemli bir bilim kadınıdır. Uluslararası Anıtları koruma ve restore etme kuruluşunun üyeliğini de yapmıştır.

\section{Minyatür Yorumları}

Orta Asya Minyatürleri adındaki bu kitap, Sovyet döneminde gelip geçmiş olan en önemli sanat tarihçisi olan Galina Anatolyevna Pugaçenkova ve onun 
öğrencisi Galerkina tarafından kaleme alınmıştır. Kitap uzun ve zahmetli bir çalışmanın sonucu ortaya çıkmıştır. Kitapta Orta Asya’da resim sanatının kronolojik gelişim süreci kültürel, siyasi ve dini oluşum süreci içerisinde geçirdiği evreler ve değişiklikleri net bir şekilde anlatılmıştır. Pugaçenkova'nın uzun yıllar boyunca biriktirmiş olduğu tecrübesi ile kitap daha da renkli ve akıcı bir şekil almıştır. Kitaptaki minyatürler, Özbekistan, Rusya, Fransa ve Amerika’da bulunan eserlerden oluşmaktadır. Renkli, siyah-beyaz ve tamamlanmamış toplam olarak 72 adet minyatür bulunmaktadır. Kitabın giriş kısmında İslam öncesi resim sanatı ve Özbekistan'ın çeşitli bölgelerinde bulunan renkli freskler, saray ve evlerdeki resim sanatı, İslam dininin resim sanatına etkisi, soyut resim çizimine başlama, hat sanatının gelişimi, yasaklara rağmen resim sanatının nakkaşlar tarafından kâğıt üstünde devam ettirilmesi, XVII. yüzyıldan sonra resim yapmanın tamamen yasaklanması, ekollerin birbiri ile etkileşimi, ipek yoluyla Hindistan, İran ve Orta Asya ekolünün teknik özleştirmeleri ve XIX. yüzyıldaki tasvir meselesinden bahsedilmektedir.

Ayrıca minyatürlerdeki kompozisyonların döneminin önemli edebiyatçlarının divan, destan ve nasihat içeren eserleri için çizildiği tespit edilmiştir. Bunun yanında gündelik hayatta olan olaylar; dini, din dışı, savaş meydanı, hükümdar portresi, doğum anı, sevgililerin görüşme sahnesi, saray ehli vs. gibi ilginç kompozisyonlara da geniş yer verilmiştir.

Kitapta özellikle XV. ve XVII. yüzyıl minyatürlerine ağırlık verilmiş olup, bu yüzyıllarda Herat, Buhara, Semerkant, Şaş, Mavereünnehir (Amuderya ile Sirderya arasındaki küçük beylikler) ekollerinin sergiledikleri muhteşem minyatürler mevcuttur. Bu yüzyılda Orta Asya sanatı değişik minyatür ve diğer sanat dallarında kendine özgü tarzıyla ve orijinalliğiyle başarılara damgasını vurmuş̧tur ${ }^{2}$.

Minyatür konuları "Altın Zincir", "Yusuf ile Züleyha", Câmi "Şah -Nâme", Firdevsî "Bostan ve Gülistan", "Ebu'l-Hayr Han Tarihi” gibi gazellerin kıssalarını anlatan kompozisyonlardır. Bununla birlikte Sâdi, Ali Şîr Nevâi ve Nîzâmi'nin eserlerine yapılan minyatürler yukarıda adı geçen ekoller tarafından yapılmıştır. Biz bu minyatürlerin içinden 8 tanesini seçtik ve tanıtmaya çalıştık.

2 Pugaçenkova, G., Galerkina, O. Minyatyurı Sredney Azii, İzobrazitelnoye İskusstva, Moskova I970, s. 6-8. 
Kendi oturdŭ̆u ăgacın dalını kesen adam.

Sâdi, Bostan

New York Metropolitan Müzesi

II. $I 34,2$ s. $6 I$

I522-I523 Buhara

Boyutu 29.2/I9.2 cm

Sâdi'nin "Bostan" manzumesindeki mesnevilerinin bir kıssasında, bir adamın kendi oturduğu dalı testere ile kestiğini gören bahçıvan ile diğerlerini şaşkınlıkla olayı seyredip, "Bu herif bize değil, kendisine kötülük ediyor." demeleri tasvir edilir. Şair, buradaki ahmak adamı maiyetindekilere zulmeden padişah ile kıyaslamıştır. Padişah maiyetindeki insanlara zulüm etmekle ancak saltanatının temelini zayıflatmaktadır. Kıssa, felsefi boyutuyla aslında dönemin padişahına bir mesajdır, bu dünyanın fâni olup, her şeyin geçici olduğu anlatılmak istenmiştir.

Padişahtan üstün olan yoktur - diyorsun,

Ancak, derviş kanunların efendisidir

Zenginlik, bükümdarlık bir yüktür, o balde (aslinda)

Kim gerçek, Padişah mı? - O Allahin zahididir.

Sâdi'nin fikirleri minyatürde tam olarak yansıtılamamıştır. Metnin içeriği kısmen tasvir edilmiştir. Minyatürdeki geometrik çizimlerin simetrikliği ve temiz çizimi Mavera nakkaşlarına ait olduğuna delalet eder. Merkezde büyük bir ağaç ve onun üzerinde kendi oturduğu dalı testere ile kesen adam çizilmiştir. Onu hayretle seyreden bahçıvan, yan tarafta iki tane ince ağacın önünde oturan derviş ile delikanlı resmedilmiştir. Buradaki tüm karakterler kıssadan alınmıştır. Her bir karakterin yüz hatlarındaki mimikleri ve giyimleri farklı çizilmiştir. Ayrıca etrafta çeşitli çiçek türleri, yeşillikler, vadiler ile resim mükemmel bir şekilde tamamlanmiştır³.

3 Türkiye'de Sâdi'nın Bostan ve Gülistan eserini Kilisli Rıfat Bilge tercüme etmiştir. Şeyh Sâdi Şîrazi, Bostan ve Gülistan, Can Kitabevi, 1968. Ayrıca bkz, Ebu Abdullah Muslihuddin Sa'di-i Şirazi, Kitabu Gülistan bi’t-Türki, haz. Ali Fehmi Karamanlıŏlu, trc. Seyfi Serayi, Ankara: Milli Eğitim Bakanlığı, 1978. 
MUHLİSE RUSTAMOVA

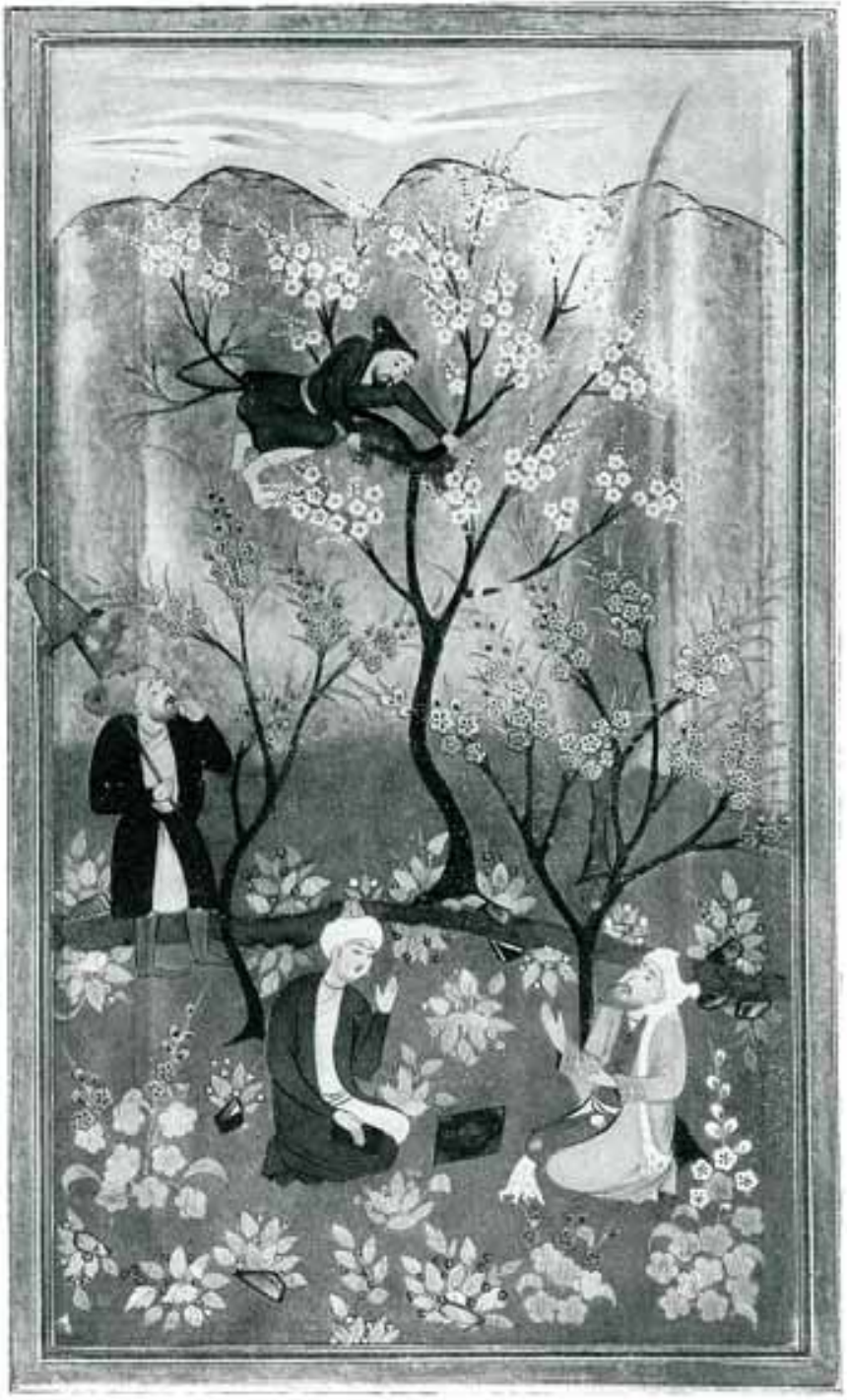


Muhammed Murad Semerkandî

Rudabénin doğumu

Firdevsî Şahnâme

Özbekistan Şarkiyat Akademisi

I8II, s. $49 b$

I556-I557, Orta Asya

Boyut 5, 8/I7cm

Firdevsi'nin Şahnâme’sinden alınan bir sahnedir. Bahadır Rüstem’in doğum anı tasvir edilmiştir. Genelde bu gibi sahneler şatafatlı bir odada gururlu bir anne ve ona övgüler yağdıran çok sayıda ziyaretçiler ile birlikte resmedilir, ancak buradaki sahne oldukça sadedir. Nakkaşın, felsefi boyutu ele almak istediği ortadadır. Sade odadaki Rudabe'nin acıları, sabrı ve umudunu tasvir etmek istemiştir. Minyatürdeki asıl amaç anne çilesini göstermektir. Hüznün hâkim olduğu kompozisyondaki boyalarda da hâkim renk mavimsi mordur. Sahnede Rüstem'in babası olan Zâl endişelidir, dua etmektedir. Diğer tarafta perdenin arasından bakan ebe duruyor. Ortada Rudabe'nin iki arkadaşı onu kollarından tutarak teselli etmektedirler. Rudabe ise acılardan dolayı kaşları gergindir, başörtüsünden dağılan saçları görünmektedir, mecalsiz bir şekilde salıverilmiş kolları ile minyatürde olağanüstü gerçeklik hissettirmiştir.

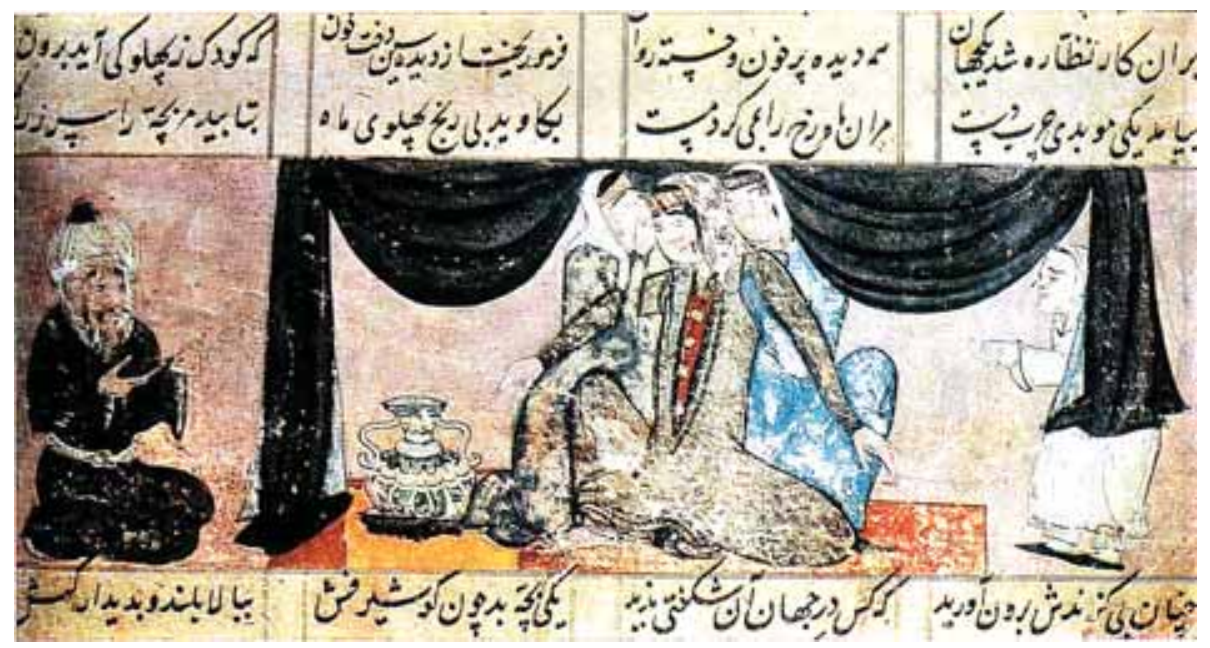


MUHLİSE RUSTAMOVA

Seyehatçı Tosbă̆a / Kaplumbă̆a

Câmi Tuhfetül-Ahrar

M.E. Saltıkova Şedrina Devlet Halk Kütüphanesi

Dorn, 425, s. $46 a$

XVI. yüzyılın ikinci yarısı Buhara

Boyut : 22/I3

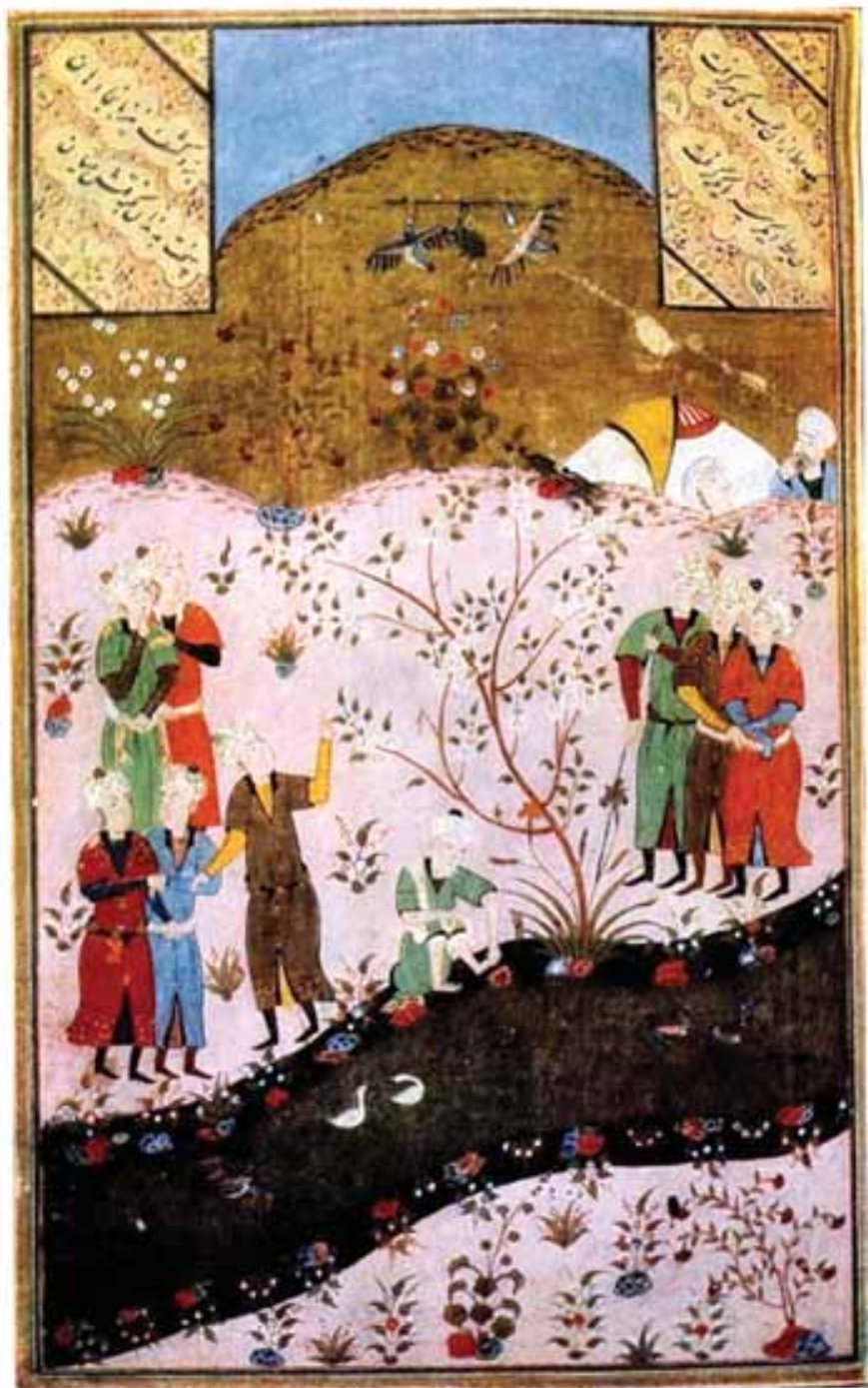


Câmi'nin Tuhfetüll-Ahrar gazeli yirmi bölümden ibarettir her bir bölümün sonunda bir darbı mesel anlatılmıştır. Onların içinde seyahatçi kaplumbağa kıssası vardır (Ruslarda seyahatçi kurbağa versiyonu var). Tosbağa uzun bir çubuğu dişleyip, başka ülkeye uçmaya hazırlanan ördeklere onu da götürmelerini rica eder, buna zor ikna olan ördekler sonunda razı olurlar. Kaplumbağaya gökyüzündeyken konuşmamasını tembihlerler. Ördekler onu gökyüzüne yükseltirler, kuşlar tarafından gökyüzüne yükseltilen kaplumbağa çok mutlu olur ve aşağıdakilere övünmeye başlar. Ben uçuyorum, duydum duymadım demeyin - diye bağırmaya başlar ve ağzını açtığı için tutunduğu çubuktan kayar ve yere düşüp parçalanır. Sonuç olarak bir geveze eğer düşünmeden konuşur veya hareket ederse sonu hüsran olur ve cezalandırılır. Bir bakıma nasihat veren bir kıssadır.

Bununla birlikte minyatür diğer karakterler ile bir bütünlük içinde çizilmiştir. Resimdeki karakterlerin tarzı XVI. yüzyıl insanlarının vasıflarını taşır. Birbirinden farklı desenlerdeki elbiseli insanlar gökyüzünde uçan kaplumbağaya hayretle bakıyorlar. İleride vadinin arkasında, yarısı görünen çadırın önünde bir hanım ile erkek birbiriyle konuşmaktadır. Etrafta çiçekler, yeşillikler ve ağaçlar var. Koyu renkte akan nehirde ördekler yüzmektedirler. Ancak bir yaşlı adamın tüm olanlara aldırmadan nehirde ayaklarını yıkaması ilginçtir.

Orta Asya minyatürlerindeki renklerin canlı ve parlak olmasına karşın bu minyatürde keskin ve koyu renkler kullanılmıştır. Yumuşak geçişlerin yerine belli çizgilerle ayrılmış renkler kullanılmışır.

Güzel ve ona âşık olan yaşlı adam.

Câmi Tühfetül-Ahrar

M.E. Saltıkova Şedrina adındali Devler Kütüphanesi

Dorn, 425, s. 58

XVI. yüzyllın ikinci yarısı Buhara

Boyut: 22/I3

Câmi’nin gazellerindeki başka bir kıssanın konusu ise şöyledir; Bir ihtiyar çiçeklerle dolu bir bağda örtüsüne bürünmüş güzel bir kadını görür ve ona aşık olur. $\mathrm{Bu}$ arada rüzgâr eser ve bayanın başörtüsünden griye dönüşmüş saçları gözükür. Bunu gören ihtiyar hemen ondan yüz çevirir. Güzel pardösüsünü yere atar ve onun yaşlı olmadığını gören ihtiyar neden onu aldattığını sorduğunda kadın şöyle cevap verir: "Senin için ihtiyar kadın ne kadar itici ise, benim için de senin gibi genç kıza izhâr-1 aşkta bulunan ihtiyar itici gelir." der. 
Cami'nin Tuhfetül-Ahrar adlı eserine işlenen bu minyatürde saray ahalisi çizilmiştir. Yaldızlı köşkteki camdan aşağı bahçede olanlara hayretle bakan bayanların yüz hatları net çizilmiştir. Arka bahçedeki uzun, ince ve narin badem ağacı, beyaz pardösülü güzel kadının duruşunu sanki tekrarlıyor gibi izlenim verir. Parlak renkler ise dramatik bir konu olmasına rağmen minyatüre bayram havası vermiştir.

Minyatürdeki geometrik desenler cetvelle net bir şekilde çizilmiştir. Kahramanların yüz şekilleri ve giyim kuşamlarının incelenmesi sonucu minyatürün Buhara ekolü tarafından çizildiği tespit edilmiştir.

Nakkaş, Câmi'nin eserinin manasını minyatürde bariz bir şekilde çizmiştir. Minyatür ihtiyarın yaşı ile uyuşmayan isteği, gençliğe karşı özentisini anlatan hüzünlü bir kompozisyondur. Ancak renklerdeki canlılık ve şenlik ağır hikâyeyi perdenin arkasına gizlemiş gibidir.

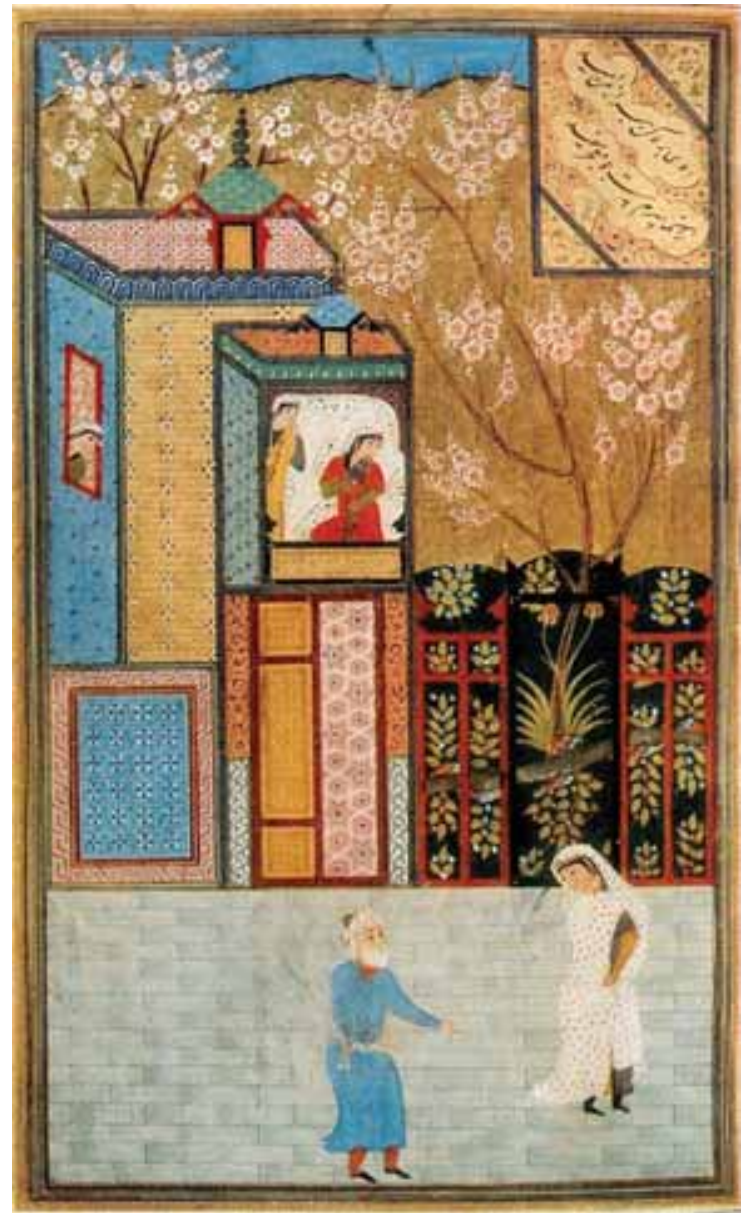


Şeyh Sanian

Nevâi Lisanu't-Tayr

Paris Milli Kütüphanesi

Suppl. Türk, 996 s.25

I553, Buhara

Boyut II,2/I2 cm

Lisanu't-Tayr' ın konusu, tasavvufun temel düşüncesi olan Allah'ın isimlerinin tecellilerinin insanda belirmesidir. Günlerin birinde her yerden gelmiş kuşlar bir araya toplanırlar. Aralarından başkan seçmek isterler. Herkes kendisinin başkanlığa en layık olduğunu öne sürer. O sırada Hüdhüd adında bir kuş, kuşların Simurğ adında bir padişahı olduğunu, onun vasıflarını öğrenmek için bizzat ona gidip görülmesinin gerekli olduğunu söyler. Böylece uzun ve zorlu bir yolculuğa çıkarlar. Yolculuk sırasında Hüdhüd kuşların sorduğu her soruyu cevaplayıp, ardından bir kıssa anlatır. Bu kıssalardan bir tanesi de Şeyh San'an kıssasıdır. Şeyh San'an hikâyesi aşkın kudretini gösteren ve aşktan dolayı yapılan tüm kabahatlerin Tanrı indinde bağışlanacağını belirten bir kıssadır. Cevhere ulaşmak için nefsin istediği her şeyden vazgeçmek gerekmektedir. Şeyh San'an Mekke'de ikamet eden bir âlim, abid ve zahid zattır. Ettiği duaların kabul olması onu her yerde ünlü kılmıştır. Halinden pek memnundur. Bir gün rüyasında bir Rum güzelini görür ve rüya aylarca tekerrür eder. Şeyh Rum güzeline âşık olur ve onu bulmak için müritleriyle yola çıkar. Rum diyarına gelir ve kızı aramaya başlar. Ağlar, sızlar, geceleri uykusuz geçirir. İbadetini aksatır. Eleme dayanamayıp müritlerinden yardım ister. Müritleri ibadetine dönmesini, oruç tutmasını, tövbe etmesini tavsiye etseler de oralı olmayan şeyh perişan bir dervişe dönüşür. Müritler ondan utanır ve birer birer onu terk etmeye başlarlar. Olan biteni duyan kız şeyhe gelir, şeyh onu görüp mutlu olur ve izhar-1 aşkta bulunur. Kız onu azarlar, ancak şeyh oralı olmaz. Kız şeyhin İslam'ı terk etmesini, domuz eti yiyip, domuz çobanlığı yapmasını, Kur'an sayfalarını yakmasını, şarap içmesini ve beline zünnar bağlamasını ister. Şeyh hepsini yapar. Rum halkı sarhoş şeyhle dalga geçmeye başlar. Bundan muzdarip olan şeyh onları ve dinlerini kınar ama yolundan dönmez. Bu arada vaktiyle şeyhten eğitim almış müridi onu ziyaret için başka diyarlardan Mekke'ye gelir. Olanları öğrenince çok üzülür ve diğer müritlere: insan on köpek baksa hiç olmazsa beşi ona hayatı boyunca sadık kalır, peki siz ne yaptınız!” der. Şeyhini geri getirmek için yola koyulur, müritler hatalarını anlayıp ona katılırlar. Şeyhini domuzları otlatırken gören mürit ona acır ve gece gündüz ağlayıp Allah’a dua etmeye başlar, bir gün imsak vaktinde yarı uykulu yarı ayıkken Peygamberi görür ve müjde alır. Şeyhinin aklı başına gelmiştir. Mekke’ye dönebilirler. Kalbindeki boşluk dolmuştur. Şeyh hamdı, yandı ve pişti. Allah sonunda ona lütfetti. Bu arada Rum güzeli rüyasında 
Hz. İsa’yı görür. Peygamber onu azarlar, büyük bir hata yaptığını, şeyhin aslında Allah'ın çok sevdiği kulu olduğunu, hemen ondan özür dileyip dinine girmesini söyler. Kız çok pişman olur ve şeyhin peşine düşer, çölde hastalanır ve bitap düşer. Şeyhe bu durum belli olur, kızı bulur. Kız özür diler ve Müslüman olarak orada vefat eder. San'an Mekke'ye döner, ölene dek İslam'a hizmet eder.

Resimde domuzları otlatmakta olan evliyanın düştüğü durum bir Müslüman için aşağılayıcı haldir. Onu görmeye gelen müritleri acıyla eleştirerek şeyhlerine bakmaktadırlar. San'an'ın yanında ise pis ve azgın domuzlar vardır. Ressam Nevâi'nin kıssasını net bir şekilde çizebilmiştir. İnsanların yüzlerindeki mimikler, çöl tasviri, figürler, renklerdeki uygunluk bu minyatürün Buhara ekolüne ait olduğuna delalet eder.

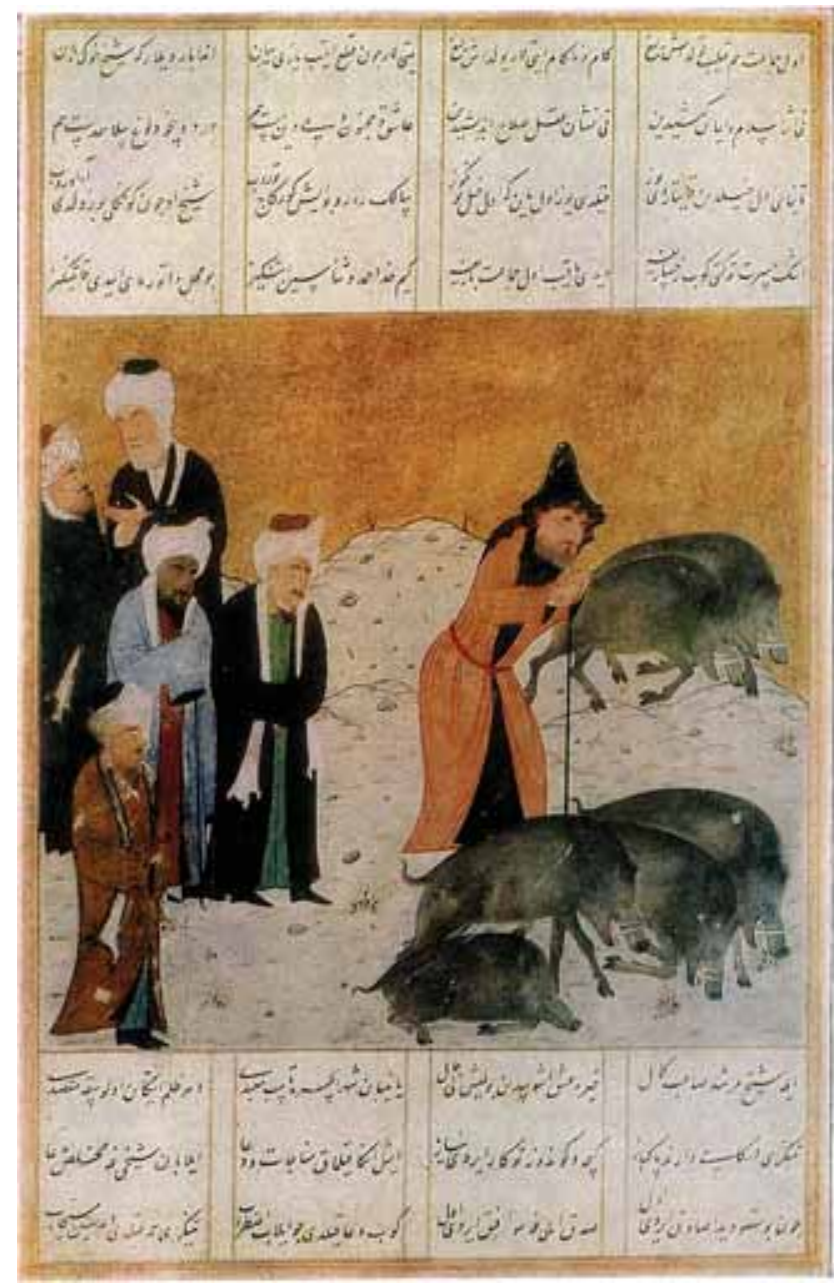


Hz. Muhammed'in Burak ile Miraca yükselmesi Emir Hüsrev Dehlevi Hızır Han Tarihi M.E. Saltıkova Şedrina Milli Kütüphanesi, Leningrad

Iran Serisi, I598, Buhara

Boyut: 25,3/I4,3cm

Minyatürde Hz. Muhammed'in miraca yükseldiği olay anlatılmaktadır. Peygamberin bineği, Burak adında fantastik bir varlıktır. Burağın baş kısmı doğu kadınının tipini andırır. Başında tacı, boynuna kadar uzanan hafif dalgalı saçı, kulaklarında küpeler, keman kaşlar, badem gözlü, kemikli burnu, küçük ağzı, geniş yüzü vardır. Gövdesi geyik gövdesini andırır. Uzun kuyruğu vardır. Burağa bindirilmiş vaziyette çizilmiş Hz. Peygamberin yüzü açıktır; başında sarığı var, uzun saçlı ve seyrek sakallıdır. Üzerinde çiçek desenli sade elbisesi var. Ayaklarında terlikleri var. Gökyüzü koyu ve açık mavi ile boyanmıştır. Hz. Peygamberin etrafında ona yemek sunan, bulutları kovarak yol açan, bayrak taşıyan, başlarında tacı, omuzlarında kanatları olan melekler insan kılığında çizilmiştir. Bu motiflerin, Budistlerin gökyüzündeki varlıklar -Aspara ve kutsal bulutlar- Bao Yün'den etkilenerek çizilmiş olabilme ihtimali vardır.

Gözlemlerden çıkarılan sonuç Orta Asya ve İran sanatındaki XIV. yüzyıla ait resimlerdeki bazı karakterlerin, diğer ülke ve dinlere mensup olan insanların sanatından alındığıdır. Örneğin doğaüstü güçlerin tasvir edildiği minyatürlerde; melekler, cinler yabancı kaynaklarda (Budist ve Hint Mitolojileri) ve gökyüzünde var olduğuna inanılan ancak görülmeyen fantastik varlıklar gibi karakterlerden İslami motif ve sembollere uyarlanarak alınmıştır. 
MUHLİSE RUSTAMOVA

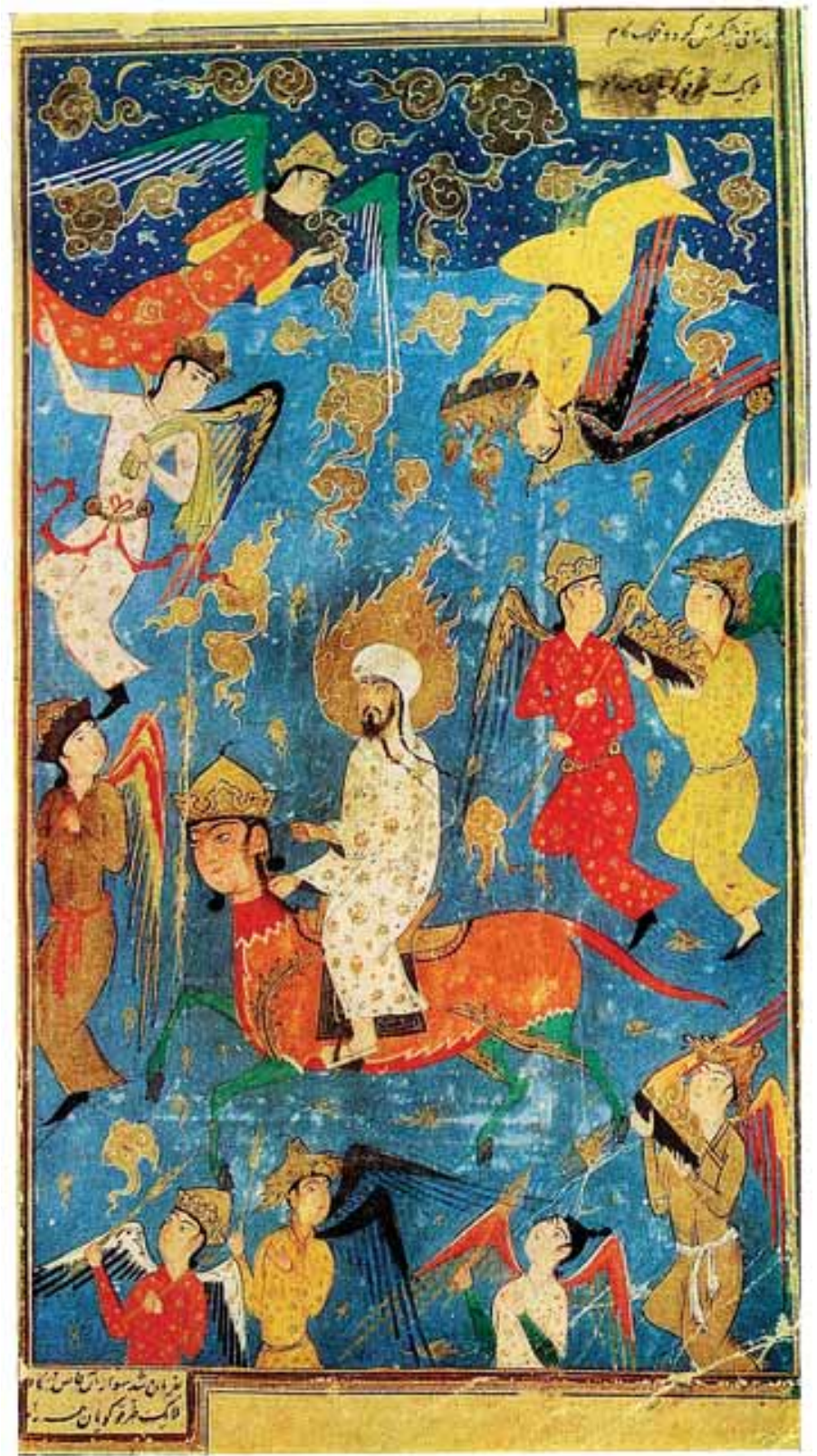


Muhammed Mukim

Boğayı taşıyan Fitne (Fettan)

Nizami Hamse

Chester Beatty Kütüphanesi Dublin

Pers 276, s. $I 7 I$

I668-1667, Buhara

Boyut: $13.4 .8,5 \mathrm{~cm}$

Nizami'nin eserlerinin çoğu aşk ağırlıklı olmakla birlikte, nasihat tarzı konular da mevcuttur. Minyatürde yedi güzeller gazelindeki bir bölümde Behram Şah ve onun sevgilisi Fitne arasındaki olay tasvir edilmiştir. Behram Şah bir gün ava giderken Fitne'yi de yanına alır. Ok atma maharetini göstererek övünmeye başlar, ancak Fitne bu duruma pek hayranlık göstermeden, aslında bu yeteneğin çok çalışmanın bir sonucu olduğunu pervasızca söyler. Fitne’nin sözüne çok kızan Behram onun katledilmesini maiyetindekilere emreder. Bir ihtiyar Fitne'yi askerlerden kurtarır ve kızı evine gizler. Bu arada Fitne küçük bir buzağıyı her gün sırtına alıp merdivenden çıkıp egzersiz yapmaya başlar. Aylar geçer buzağ büyür, Fitne’nin de gücü çoğalır. Fitne'yi katletme emri verdiği için kendini affedemeyen Behram perişan olur. Günlerden bir gün evin ikinci katında dinlenirken merdivenlerden sırtına kocaman boğa yükleyerek kendisine doğru çıkan birini görür ve şaşkınlıktan dili tutulur. Boğayı yere indiren kadının Fitne'nin ta kendisi olduğunu görünce çok sevinir. Fitne’nin bu halinin, ancak uzun bir idmanın sonucu olduğunu söyleyen Behram'a cevabı şöyle olur: "Gördün mü, uzun egzersiz nelere kadir yapar insanı, bana olağandışı güç, sana ok atma becerisi."

Boğa taşıyan Fitne konusu çok kez çeşitli ressamlar tarafından çizilmiştir. Ancak Buhara versiyonunda geometrik düzen, insanların yüz hatları, Fitne’yi kurtaran ihtiyar, merdivenden boğayı sırtlayarak çıkan Fitne, Behram Şah net bir şekilde çizilmiştir. Musikişinaslar ile korodakiler şaşkınlıkla Fitne’ye bakar vaziyette resmedilmişlerdir. Ev, XVII. yüzyılda Buhara evlerinin tipik örneğidir; iki katlı, teraslı, sütunlu, süslemeli motifleri ile varlıklı birinin evi olduğunu gösterir.

Boğayı sırtında taşıyan Fitne sahnesi birçok ekollerde tekrar çizilmiştir. Bu minyatürlerden biri günümüzde Topkapı Sarayı Müzesinde bulunmakta olup, 


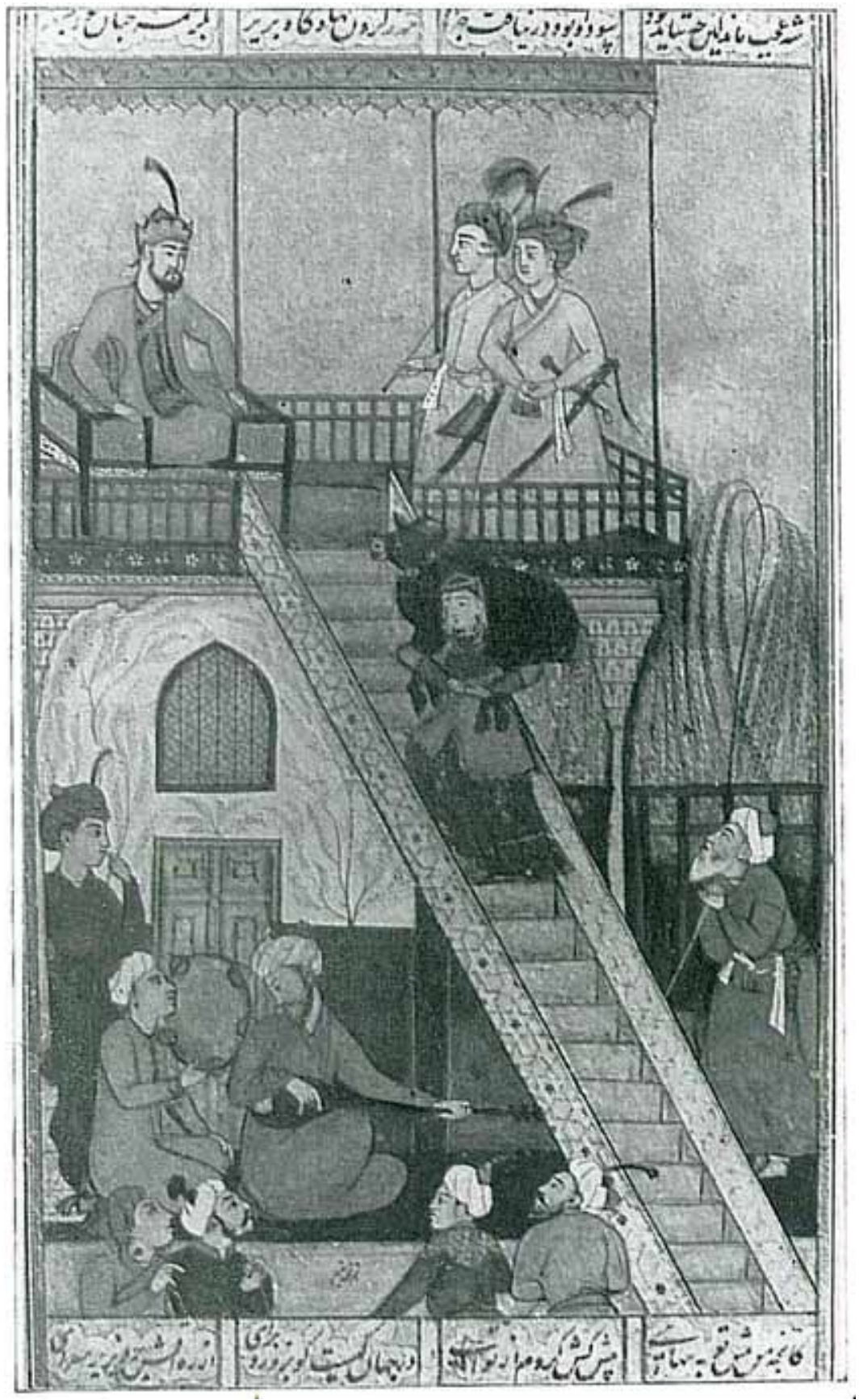


İvan Stchoukine onun üzerinde çalışma yapmıştır. (Resim I,2,3) Nizami'nin Hamse'si Azerbaycan'da Mehmed Cafer Caferov ve ekibi tarafından Azerbaycanca, Rusça ve İngilizce dillerine çevrilmiş, Mikail Abdullayev çizimiyle yeniden resmedilmiştir`. (Resim 4)

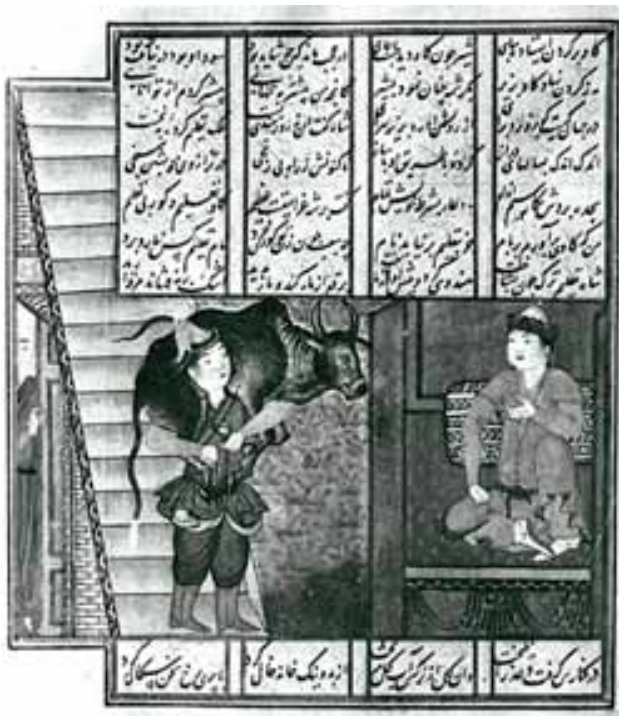

b) VITNEH. FORTANT UN JEUNE BCUY, DEVANT MAHRÂM Mleme mahuacrit, fol. 203.

Resim I

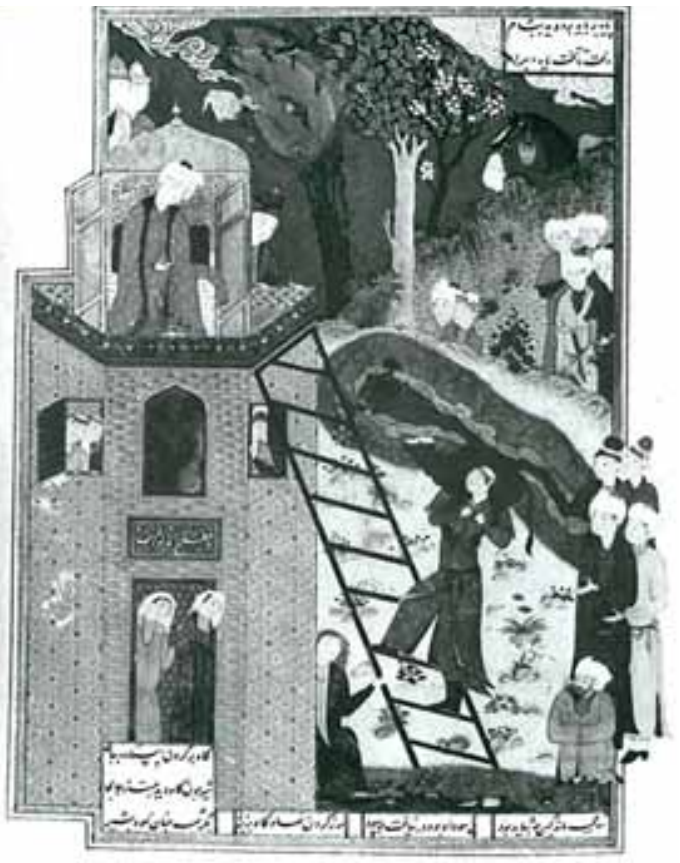

a) FITNEH, FORTANT UN JEUNE BCUF, MONTE VEHS AAHRTM Manuscrin ot XIII, date de 586/1481, a Tabris, Ga. 167.

Resim 2

4 İvan Stchoukine, Les Peintures Des Manuscrits De La "Khamseh" De Nizâmî, Aau, Topkapı Sarayı Müzesi D’istanbul, Librairie Orientaliste Paul Geuthner yay, Paris 1997.

5 Mehmed Cafer Caferov, Nizami "Khamsa" motifs in Mikail Abdullajev’s works. Işıg yay, Baku ı99o. 


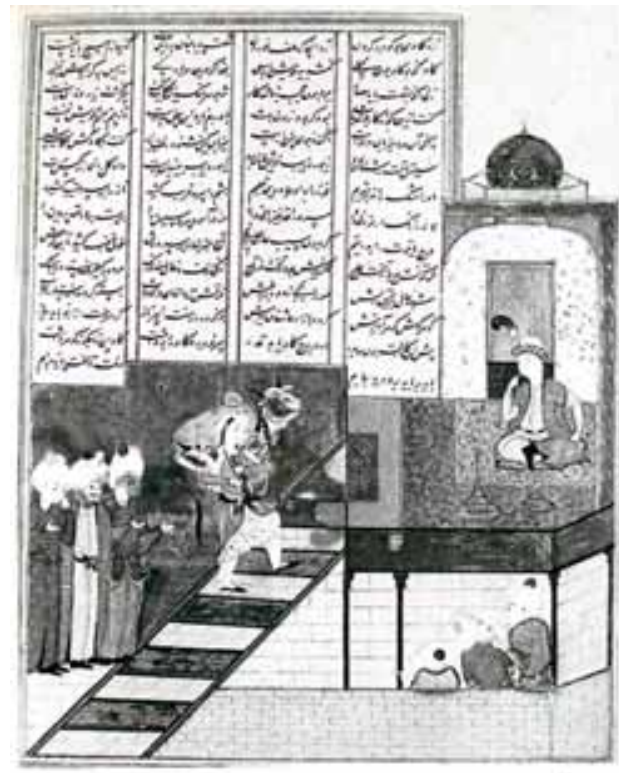

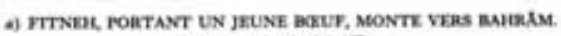
Mime nanienis, Ma is7 *

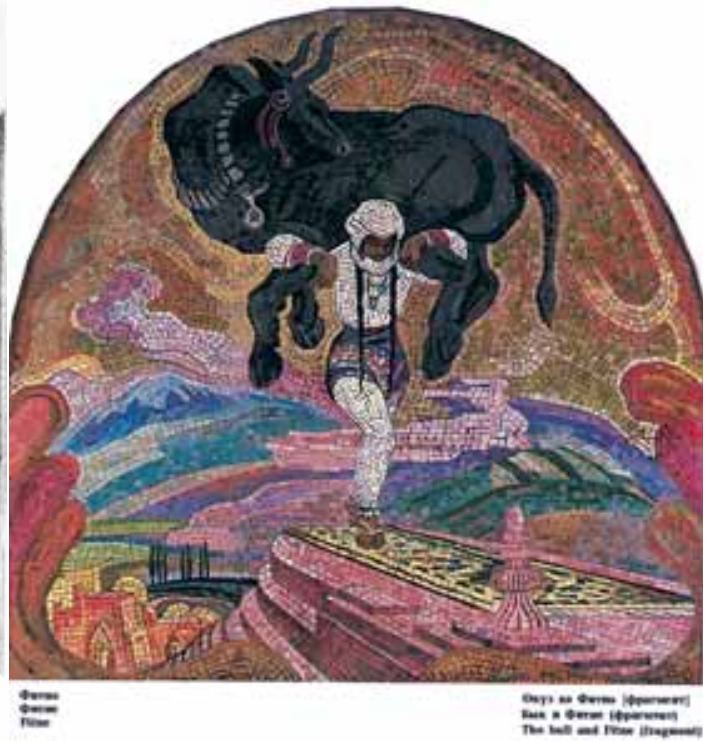

Resim 4

Hükümdarın Kadıyı sarhoş olarak yakaladı̆̆ı sahne.

Sadi, Gulistan

I566-1567 Buhara ekolü

Boyut:25/I5 cm

"Aşk ve Gençlik" hakkında öğretici bir hikâyedir. Yaşlı kadı (yargıç) genç ve güzel bir kadına âşık olur ve onun evinin önüne gelip ağlar sızlar, içki içer, sarhoş olur. Bunu duyan padişah, durumu bizzat görmek için kadının haberi olmadığı bir zamanda kadının evine gelir ve gerçekten onu sarhoş bir halde yakalar.

Minyatürde mimari yapılarlardaki cepheler süslenmiştir, köşk odaları üç boyutlu olarak gösterilmiştir. Resmin yukarıdaki bölümünde harem ve pencerelerinden bakan iki bayan; yan taraflarda korkuluklar ve arka tarafta bağ bahçe, avluda ise sarhoşluktan şuurunu kaybetmiş kadı ve yanında ona arkadaşlık eden adam, oturduğu yerde sızıp kalmış bir vaziyette resmedilmiştir. Padişah bu durumdan 
hiç hoşlanmadığı ve yargıladığı bu adamın kadılı̆̆ hak etmediğini düşünmüş bir şekilde resmedilmiştir. Kapıdaki hizmetçi korkarak olanları izlemektedir. En alttaki sahnede padişahın maiyetindeki hizmetliler ve atı resmedilmiştir.

Minyatürdeki sahne birçok olayı izleyiciye aktarmaktadır, zor bir çalışmadır, bir kaç kompozisyon, olay aynı anda aktarılmaya çalışılmış, perspektif ve boyut yardımıyla canlı cansız tüm ayrıntılar aktarılmaya çalışılmışıır. Bütün bunlar sarhoş kadı ve sızmış delikanlının etrafında oluşmakta dolayısıyla iki sarhoş konunun özünü teşkil etmektedirler. Ayrıca Mavera ekolünde ender kullanılan karanlık gökyüzü gri ay ve yıldızlar dikkat çekicidir.

İşbu minyatür İ́ran Safevi ekolünün yeniden ikinci hayat bulmasının açık kanitidir.

Makalede, XVI. ve XVII. yüzyılda Orta Asya'daki çeşitli minyatür ekolleri tarafından çizilmiş olan minyatürler verilmiştir. Minyatürlerin konuları bir birinden farklıdır; dini, sivil, saray ehli, nasihat tarzı, ders çıkarma gibi konular içermektedir. Minyatürler, Sadi'nin Bostan'1, Gülistan'1, Firdevsi'nin Şahname’si, Cami'nin Divan' ', Nevai'nin Hamse'si, Emir Hüsrev Dehlevi'nin Hızır Han Tarihi, Nizami'nin Fitne adlı eserlerinden esinlenen nakkaş camiası tarafından büyük bir titizlikle çizilmiştir. Ayrıca aynı konuları anlatan birçok minyatür dönem dönem tekrar çizilmiştir. İncelemiş olduğumuz kitaba sadık kalarak, minyatürün anlatım şeklini olduğu gibi verdik. Burada minyatürün bilgileri, eserin müellifi, konunun kısa özeti, ekol tespiti, renk ve çizim analizi bulunmaktadır. Aynı zamanda Pugaçenkova'nın eşsiz yorumuyla ayrı bir boyut kazanmakta, fikir vermektedir.

\section{İlmi Çalışmaları}

Özbekistan Sanatı, «İskusstvo Uzbekistana» Orta Asyảnın birçok ülkesindeki üniversitelerde ders kitabı olarak okutulur.

Pugaçenkova’nın editörlüğünü yaptığı birkaç ciltlik Özbekistan'ın Mimari Anıtları adındaki ilmi çalışma uzman bir grup tarafından hazırlanmıştır.

Bununla birlikte Pugaçenkova 750'den fazla bilimsel kitap ve makalenin yazarıdır. Çalışmaları birçok dile çevrilmiştir. Bu çalışmalarından dolayı Guinness Rekorları Kitabı'na giren tek bilim kadınıdır.

I. Пугаченкова Г. \& Ремпель Л., Бухара. (Узбекистан). (Серия «Сокровища зодчества народов СССР»). М., І949.

Pugaçenkova, G. \& L. Rempel, Buhara. (Özbekistan). (Seri "SSCB mimarisi Hazineleri”). M., I949. 67 s. 6000 adet. 
MUHLİSE RUSTAMOVA

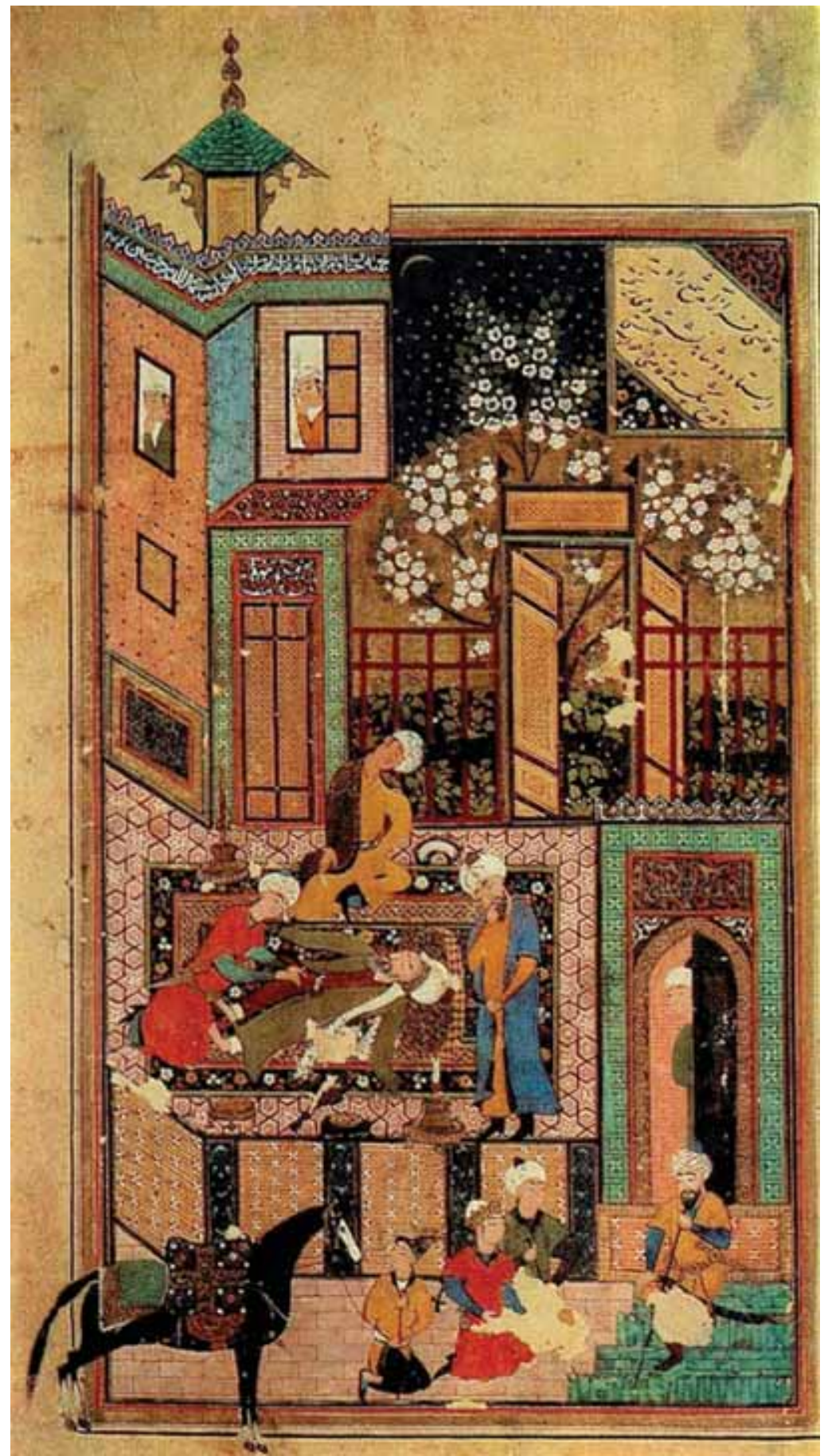


2. Массон М. Е. \& Пугаченкова Г. А., Гумбез Манаса. (Киргизское зодчество. XIV в.) (Серия «Памятники архитектуры народов СССР»). М., І950.

Masson M. E. \& Pugaçenkova, G. A., Manas’nn Türbesi. (Kırgız mimarisi. XIV yüzyıl). (Seri “SSCB’nin Anıtlar”). M., I950. I44 s. 4000 adet.

3. Пугаченкова Г. А. \& Елькович Л. Я., Очерки по истории искусства Туркменистана. Аш., 1956.

Pugaçenkova, G.A. \& Elkovich L.Y., Türkmenistan Sanat Tarihi Denemeleri. Aş., I956. I47 s. 5000 adet.

4. Массон М. Е. \& Пугаченкова Г. А., Парфянские ритоны Нисыл. Альбом иллюстраций. М., 1956.

Masson M.E. \& Pugaçenkova, G. A., Pers Nisa Ritonları Kataloğu, M., 1956

5. Памятники архитектуры Средней Азии эпохи Навои. Ташкент, І957.

Orta Asya Mimari Anıtlar, Nevai Dönemi. Taşkent, I957. 98, s. 500 adet.

6. Пугаченкова Г. А. \& Ремпель Л. И., Выдающчиеся памятники архитектуры Узбекистана. Ташкент, I958.

Pugaçenkova, G. A. \& L. I. Rempel, Özbekistan'ın Seçkin Mimari Anıtları. Taşkent, I958. 292 s. 5000 adet.

7. Пути развития архитектуры южного Туркменистана поры рабовладения и феодализма. (Труды ЮТАКЭ. Т.6). М., Изд-во АН. 1958.

Güney Türkmenistan'ın Kölelik Devrinden Feodal Döneme Kadar Mimari Gelişim Süreci, (YTAKE Tutanakları. T.6). Moskova Bilimler Akademisi. I958. 492 s.

8. Массон М. Е. \& Пугаченкова Г. А., Парфянские ритоны Нисы. (Труды ЮТАКЭ. Т.4). Аш., Изд-во АН. 1959.

Masson M. E. \& G. A. Pugaçenkova, Pers ve Nisa Ritonları, (YTAKE Tutanakları. T. 4), Aş., An., yay, I959, 268 s.

9. Мечеть Анау. Аш., I959.

Anav Mescidi, Aş., I959, 58 s. I000 adet.

го. Пугаченкова Г. А. \& Ремпель Л. И. Выдающиеся памятники изобразительного искусства Узбекистана. Ташкент, І96о.

Pugaçenkova, G. \& L. Rempel, Özbekistan'ın seçkin mimari anıtlarında süslemeler, Taşkent, I960, 328 s, 5000 adet. 
II. Искусство Афганистана. Три этюда. М., Искусство. 1963. Afganistan Sanatt, Ü̧̧ Çalışma, İskusstvo yay, 1963, 248 s, 3500 adet.

12. Мавзолей Араб-ата. (Из истории архитектуры Мавераннахра IX-X вв.). Ташкент, 1963.

Arap Ata Türbesi, (Mavereünnehir Anıtsal Mimari Taribi IX-Xyy), Taşkent, I963, II8 s.

13. Пугаченкова Г. А. \& Ремпель Л. И., История искусств Узбекистана с древнейших времен до середины девятнадиатого века. М., Искусство. 1965.

Pugaçenkova, G. \& L. Rempel, Antik Çă̆dan XIX. Yüzyıla Kadar Özbekistan Sanat Tarihi, M., İskusstvo 1965, 688 s, 3600 adet.

I4. Халчаян. К проблеме художественной культуры Северной Бактрии. Ташкент, Фан. 1966.

Halçayan, Kuzey Baktriya’nın Medeni Sanatı Problemleri, Taşkent, Fan yay, I966, 287 s, I500 adet.

15. Искусство Туркменистана. Очерк с древнейших времен до 1917 г. М., Искусство. 1967.

Eski Dönemlerden I9I7 Yılına Kadar Türkmenistan Sanatı, M., İskusstvo yay, I967, $327 \mathrm{~s}, 5500$ adet.

16. Самарканд. Бухара. (По древним памятникам). (Серия «Архитектурнохудожественные памятники городов СССР»). М., Искусство. 1961.

Samarkand, Buhara, (SSCB Şehirlerindeki Anıtsal Mimari Sanat Eserleri Dizisi), M., İskusstvo, 196I, 213 s, I0000 adet, ikinci bask1, 1968, 203 s, 50000 adet.

17. Скульптура Халчаяна. М., Искусство. г97І.

Halçayan Heykelleri, M., İskusstvo, I97I, 202 s, 6000 adet.

18. Зодчество Центральной Азии, XV век: Ведущие тенденции и черты. Ташкент, 1976.

XV. Yüzyılda Orta Asya Mimarisinin Başlıca Eğilimleri ve Özellikleri, Taşkent, 1976, II5 s, 3000 adet.

19. Термез. Шахрисябз. Хива. (Серия «Архитектурно-художественные памятники городов СССР»). М., Искусство. 1976.

Termız, Şahrisabz, Hiva, (SSCB Şehirlerindeki Anıtsal Mimari Sanat Eserleri Dizisi), M., İskusstvo, 1976, 207 s, 50000 adet. 
2о. Кругликова И. Т. \& Пугаченкова Г. А., Дильберджсин: (Раскопки 1970-1973 г2.). Ч.2. М., Наука. 1977.

Kruglikova, İ. T. \& Pugaçenkova G. A., Dilberçin (1970-1973 Kazıları), (Ч.2), M., Nauka yay, 1977, I35 s, 700 adet.

2I. Пугаченкова Г. А. \& Галеркина О. И., Миниатюры Средней Азии в избранных образцах: (Из советских и зарубежных собраний). М., Изобразит. искусство. 1979.

Pugaçenkova G. A. \& Galerkina, O. İ., Seçkin Örnekleriyle Orta Asya Minyatürü, (SSCB ve Yabancı Koleksiyonlardan Derlenmiştir), M., İzobrazitelnoye İskusstvo yay, 1979, 207 s, 25000 adet.

22. Искусство Бактрии эпохи кушан. (Серия «Из истории мирового искусства»). М., Искусство. 1979.

Kuşan Döneminde Baktriya Sanatı, (Dünya Sanat Tarihi Dizisi), M., İskusstvo, I979, 247 s, IOOOO adet.

23. Пугаченкова Г. А. \& Ремпель Л. И., Очерки искусства Средней Азии: Древность и средневековье. М., Искусство. 1982.

Pugaçenkova, G. A. \& Rempel, L. İ., Antik ve Orta Çă̆da Orta Asya Sanatı Üzerine Makaleler, M., İskusstvo, 1982, 288 s, 25000 adet.

24. Искусство Гандхары. (Серия «Из истории мирового искусства»). М., Искусство. 1982.

Gandhara Sanatı, (Dünya Sanat Tarihi Dizisi), M., İskusstvo, 1982, I95 s, 25000 adet.

25. Средняя Азия: Справочник-путеводитель. / Автор текста и сост. альбома Г. А. Пугаченкова. М., Искусство; Лейпциг, Эдицион. 1983.

Pugaçenkova, G. A., Orta Asya Gezi Rehberi, M., İskusstvo, Leyptsig, Editsion, I983, XLII, 427 s, 50000 adet.

26. Древний Мерв: путеводитель. Аш., 1983.

Köhne Merv: Kılavuz, Aș., 1983, 48 s, I0000 adet.

27. Шедевры Средней Азии: альбом. Ташкент, 1986.

Orta Asyảnın Şaheserleri: Albüm, Taşkent, 1986, 220 s, 20000 adet.

28. Из художественной сокровищнищь Среднего Востока. Ташкент, 1987.

Ortadoğu'nun Sanat Hazinelerinden Örnekler, Taşkent, 1987, 223 s, 5000 adet. 
29. Древности Мианкаля: Из работ узбекистанской искусствоведческой экспедиции. Ташкент, Фан. 1989.

Köhne Miankala Eserleri, Özbek Arkeologların Çalışmalarından, Taş, Fan yay, 1989, $204 \mathrm{~s}$.

3о. Пугаченкова Г. А. \& Ртвеладзе Э. В., Северная Бактрия-Тохаристан: Очерки истории и культуры: Древность и средневековье. Ташкент, Фан. I990.

Pugaçenkova, G. A. \& Rtveladze, E. B., Kuzey Baktriya ve Toharistanin tarihi ve Kültürü̈ Üzerine Makaleler, Tasskent, Fan yay, 1990, 218 s, I000 adet.

3I. Архитектурное наследие Темура. Ташкент, 1996. 125 стр. 5000 экз.

Emir Timur'un Mimari Mirast, Taşkent, 1996, I25 s, 5000 adet.

32. Пугаченкова Г. А., Ииратхана, Ташкент 1968.

İsrathana, Taşkent 1968.

33. Пугаченкова Г. А., Музей под откритом небом, Ташкент Изд Гафура Гуляма 198г.

34. Muzey pod otkritom nebom, Taşkent 198I, Gafur Gulam yay, 30,000 adet. $230 \mathrm{s.}$

\section{Kaynakça}

G. A. Pugaçenkova \& O. Galerkina, Minyatyur Sredney Azii, İzobrazitelnoye İskusstva, Moskova.

Özbek Sovyet Ensiklopediyası, Ed. Möminov, M.İ., Pugaçenkova mad, Taşkent 1977. s. 104.

Вероника Горлова , 27.07.08. Мельбурн. Вероника Горлова, 2010. Свидетельство о публикации №21001020354.

Veronika Gorlova, Melburn 27.07.08.

Мария Яновская, Жизнь по своему чертежу. К юбилею Галины Анатольевны Пугаченковой, Тигран Мкртычев. Записала М.Яновская. http://www.fergananews.com/article.php?id=6465, II.02.2010.

Mariya Yankovskaya, Pugaçenkova'nın vefatının üçüncü yıldönümü toplantısında, öğrencileri tarafından anma töreni. II.02.20IO. 
Сергей Савчук, Курбанов, кандидат исторических наук, археолог.

Prof. Dr. Sergey Savçuk, Kurbanov, Tarihçi ve Arkeolog.

«Популярная художественная энциклопедия.» Под ред. Полевого

B.M.; М.: Издательство “Советская энциклопедия”, 1986. "Büyük Sanat Ansiklopedisi" Editör Polevoy, Sovetskaya Ensiklopediya yay, V.M., 1986. 